【論文】

\title{
店舗の利用可能性からみた食料品アクセスと食品摂取
}

\author{
農林水産政策研究所（現：東京農業大学）菊島 良介 \\ 農林水産政策研究所 高橋 克也 \\ 東京大学（現：農林水産政策研究所） 伊藤 暢宏 \\ 農林水産政策研究所 大橋 めぐみ
}

\section{The Relationship between Access to Grocery Stores and Food Consumption from the Perspective of the Availability of Retail Formats}

\author{
Ryosuke KIKUSHIMA \\ The Policy Institute of the Ministry of Agriculture, Forestry and Fisheries, Present: Tokyo University \\ of Agriculture \\ Katsuya TAKAHASHI \\ The Policy Institute of the Ministry of Agriculture, Forestry and Fisheries \\ Nobuhiro ITO \\ The University of Tokyo, Present: The Policy Institute of the Ministry of Agriculture, Forestry and \\ Fisheries \\ Megumi OHASHI \\ The Policy Institute of the Ministry of Agriculture, Forestry and Fisheries
}

\begin{abstract}
:
This study focuses on the availability of retail formats to reveal what consumers purchase and their grocery shopping characteristics. The relationship between access to grocery stores and food consumption was also qualitatively examined from the perspective of retail formats.

First, an overview of the respondents' grocery-shopping environment revealed that the stores where people shop most frequently are not the closest ones. Additionally, we found that the elderly tend to shop less frequently and spend less money on shopping trips, as they have limited access to grocery stores. This finding suggests that they cannot compensate for the low shopping frequency by buying in bulk, potentially affecting their food diversity and the frequency of consuming fresh food.

We then created subsamples by dividing the respondents into those who drive to visit the stores where they shop most frequently and those who do not. We estimated a Tobit model using the food consumption diversity score and the frequency of consumption as the objective variables, and the retail format's availability as the primary explanatory variable. The results indicated that the distance to the stores where people shop most frequently is greater when they drive to the store. People maintain diversity by additionally purchasing vegetables and fruits at convenience stores (hereafter "CVSs"). The results suggest that the availability of vegetables and fruits at CVSs potentially affects the diet of the elderly who can drive or have access to cars.
\end{abstract}


Keywords: availability of retail formats, access to grocery stores, food environment, food consumption, convenience store

\section{1.はじめに}

食料品アクセス問題が取り沙汰されて久しいが、 その背景の一つとして食料品店の減少を指摘でき る。食料品店の減少は、郊外での大規模商業施設 の開店による旧市街地の小売店の閉店といった小 売業態の変遷も影響している $[1]$ 。

経済産業省『商業統計表』によれば、小売業全 体の事業所数は1982年以降減少傾向が続いており、 1982年では172万店であったが2014年では78万店 となっている。小売業全体の販売額も1990年代を ピークに減少・停滞傾向にある。一方で、コンビ ニエンスストア（以下、コンビニ）は、数ある小 売業態の中でも堅調に店舗数および販売額を拡大 させている（註 1$)$ 。近年では、野菜や果物の他、 一部の精肉など生鮮食品の取り扱いも始めており、 コンビニは消費者の食料品購入において欠かせな い存在となっている。農林水産政策研究所が作成 している「食料品アクセスマップ（以下、アクセ スマップ)」においても、2015年からはコンビニ を含んだアクセス困難人口が推計されている [4]。一方で、コンビニの利用に偏った食事では 脂質割合の高い食品を摂取しやすいという指摘も ある [5]。こうしたコンビニの利用拡大は消費 者の食生活にどのような影響をもたらすのであろ うか。

スーパーマーケットやコンビニといった小売業 態、すなわち消費者にとって食料品の購買チャネ ルのひとつである店舗へのアクセス性は、世界保 健機関（WHO）が健康格差に影響をもたらす要 因の一つと指摘しており [6]、健康的な食生活 を送る食環境 (Food Environment; Story et al. [7]）に関連する重要な論点である。これら食環 境と食生活や栄養摂取との関係については、医学・ 栄養学分野での研究蓄積がある。例えば、USDA [8] ではSNAP参加者にとって、スーパーマー ケットが利用可能でない場合、野菜や果物の購入 金額が少なくなることが明らかにされている。こ
の他、Morland et al. [9] はAtherosclerosis Risk in Communities (ARIC) Studyから、スー パーマーケットが近くにあり利用可能である人は、 コンビニがそうである人と比べて、過体重あるい は肥満の状態にある人が少ないことを指摘した。 複数の研究でスーパーマーケットの利用可能性と 肥満は負の関係にあり、ファストフード店の利用 可能性と肥満では正の関係が確認されているが [10]、有意な関係が認められなかった研究もあり [11][12]、一般的な結論には至っていない。

また、食料品アクセス問題に関する研究の方法 論的な限界を 2 点指摘できる。第一に、食環境の 精度と分析する対象地区の範囲の間にはトレード オフ関係があることである。すなわち、消費者の 置かれている食環境をより具体的に把握するには、 対象地区を限定せざるを得ないということである。

具体的には、店舗別の品揃えといった「食料品 充足率」が加味された先駆的な分析も実施されて いるが [13］［14］、全国規模で店舗別の食料品充 足率を把握することは不可能である。また、大橋 ら［15］は住民調查からスーパーマーケットの新 規出店が高齢女性の食生活や健康に与える影響を 分析しているが、分析対象の地区は限定されてい る。

第二に、食料品アクセス問題に関する公的統計 が存在しないことである。総務省『全国消費実態 調査』では、地域や年齢階層別といった集計レベ ルで購入先を把握できるものの、購入先と具体的 な食生活の関連は不明である。このため、全国規 模のミクロデータを用いて食環境と食生活や栄養 摂取の関係を分析した研究、特に店舗の小売業態 別のアクセス性に着目した研究は管見の限り見受 けられない。

消費者からみた食料品の購入先に焦点をあてた 研究として、伊藤ら［16］による食料品購買チャ ネルと食料品摂取の関係についての分析が挙げら れる。そこでは通信販売を含め消費者が実際に利 用する購買チャネルによって食料品の品目別に捸 取頻度の差異が示された。しかし、これは食料品 
一本研究（利用可能と利用不可能の差）

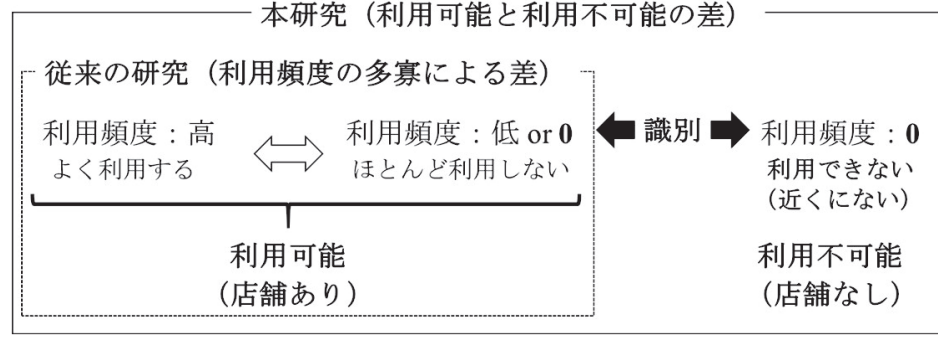

図 1 利用可能性の概念図

出所：筆者作成。

アクセスに直接焦点があてられた分析ではない。 これまでの食料品アクセスの観点からすると、伊 藤ら［16］のような購買チャネルの利用頻度の分 析では回答者の周囲に店舗が存在し、全て利用可 能であるという前提が置かれている。すなわち、 単に利用頻度を問うだけではそもそも店舗が存在 せず利用不可能な回答者が想定されていないので ある。

具体的に述べると、店舗の利用頻度を尋ねた場 合、「全く利用しない（利用頻度=0)」という回 答が得られても、回答者の周囲に店舗がないから 利用できないのか、あるいは店舗はあるが利用し ていないだけなのかを識別することができない。 そこで、本研究では店舗の利用頻度を問う設問で 「利用できない」という選択肢を設け、店舗の有 無による利用可能性を識別する（図 1 )。このこ とで、そもそも店舗が存在せず利用不可能な回答 者と店舗が周囲に存在する回答者の判別が可能と なる。アクセスマップにおいては、居住地から店 舗まで $500 \mathrm{~m}$ 以上かどうかの確率が議論されるよ うに、食料品アクセスの観点からは店舗が存在し 利用できるか否かが重要となる。食料品アクセス においては店舗までの距離だけでなく、それら店 舗が実際に利用可能かによって消費者の食環境は 大きく異なるからである。

以上のような方法論的な課題もあり、食料品ア クセス問題がもたらす食生活への影響について、 わが国における全国規模の分析は手薄く、全国的 な傾向を十分に把握できているとは言えない。ま た、食料品アクセス問題がもたらす食生活への影 響に関する全国規模の先行研究（菊島・高橋 [17］、Yamaguchi et al［18］、菊島・高橋［19]）
では、伊藤ら［16］のように購買チャネルの観点、 および店舗の利用可能性を考慮した分析には至っ ていない。

そこで、本研究では店舗の利用可能性に着目し、 まず消費者の買い物内容と特徴を明らかにする。 さらに、小売業態の観点から食料品アクセスと食 品摂取の関係を定量的に検討する。具体的には、 全国規模のミクロデータを用いて利用可能な店舗 の小売業態を確認することで、消費者が置かれて いる食環境を把握し、小売業態別のアクセス性と 食品摂取の関係を分析する。

データとして、2018年 6 月に実施された農林水 産省「平成30年度農林水産情報交流ネットワーク 事業全国調査：買い物と食事に関する意識・意向 調査」(以下、モニター調査) を用いる。このデー 夕を用いる強みは、回答者の住居が所在するメッ シュ番号からアクセスマップのデータとリンケー ジが可能な点である。このことによりアクセスマ ップで得られた最寄り店舗までの平均距離を食料 品アクセスの客観的指標として利用できる。

本研究の分析上の特徵は、各店舗の利用頻度で はなく、消費者からみて店舗が存在し利用可能な 状態かどうかに焦点をあてることである。消費者 にとって店舗の減少は利用可能な選択肢の減少で あり、この中でどの小売業態をどの程度利用する かは個人の意思決定の問題である。すなわち、利 用可能な店舗の小売業態の違いによる間接的な食 生活への影響を検討する。

以下、第 2 節にて分析の枠組みとデータの概要 を述べる。第 3 節にて回答者の食環境や食料品購 入の実態について、各店舗の利用実態や購入額等 を中心に整理する。続いて第 4 節にて店舗の利用 
可能性が食品摂取に与える影響を検討し、第 5 節 にて結論を述べる。

\section{2. 分析の枠組みとデータ}

\section{1 ）分析の枠組み}

本研究では、店舗の利用可能性に着目し、消費 者の食料品アクセスと食品摂取の関係を検討する が、購入先として総務省『全国消費実態調査』の 購入先を参考に(1)食料品スーパーマーケット（百 貨店、ディスカウントストア、ドラッグストア、 量販店も含む。以下、スーパー)、(2)地元の一般 小売店（商店、八百屋、肉屋、お弁当屋など、以 下、地元小売店)、(3)コンビニの 3 種類の小売業 態を想定する。これは比較的商圈の広いスーパー の出店による地元小売店の閉店とともに、近年存 在感を増すコンビニの影響を念頭に置いているた めである。これら 3 種類の小売業態へのアクセス 性が食品摂取にいずれも正の影響を与えることが、 本研究の仮説である。

回答者の周囲に店舗が存在するかどうかを確認 するため、店舗の利用頻度に「利用できない（近 くにない)」を設け小売業態別に集計した。「利用 できない（近くにない）」と回答しなかった場合 に 1 をとる二值変数 (以下、店舗の利用可能ダミ 一変数) を作成して分析に利用する。このことに より利用頻度にかかわらず店舗が存在するかどう かの影響の把握が可能になる。

その上でまず、回答者の食料品購入の特徵を整 理する。本研究では各店舗の利用可能性と利用頻 度とともに、利用可能な店舗のうち最も近い店舗 （以下、最寄り店舗）や利用する店舗のうち最も よく利用する店舗 (以下、最利用店舗) 、店舗ご との食料品の購入額、買い物における不便や苦労 の有無について確認している。これらの情報を活 用して回答者の買い物の実態を整理する。

次に、小売業態別にみた店舗の利用可能性と食 品摂取の関係を定量的に検討するが、食品摂取の 指標として食品摂取の多様性と各食品の摂取頻度 を用いる。食品摂取の多様性は熊谷ら［20］に従 い、得点が高いほど食品摂取の多様性に富むこと を示す多様性得点（10点満点）を利用する。各食
品の摂取頻度については週あたり日数に換算して 説明変数とした（註 2$) 。$

本研究では10品目の食品のうち緑黄色野菜、果 物類、魚介類、肉類に着目する。これらは近年生 鮮食品や袋入りカット野菜・果物等、コンビニで 取り扱いが拡大している品目でもある。また、小 売業態別にみた店舗の利用可能性を説明変数、食 品摂取の多様性得点と摂取頻度を目的変数とする 定量分析を行うが、これら目的変数はいずれも打 ち切りのあるデータのため、USDA［8］に倣い Tobitモデルを採用する。

なお、アクセスマップの定義（註 3 ）に従い、 本研究では65歳以上の高龃者を分析対象とする。 また、移動手段が自動車か否かによって回答者の 店舗の利用可能性は大きく異なることから、これ らをサブサンプルに分割して推計を行う（註 4)。

\section{2) データ}

分析に用いたデータは、農林水産省「平成30年 度農林水産情報交流ネットワーク事業全国調査： 買い物と食事に関する意識・意向調査」として 2018年 7 月に実施されたWebおよび郵送アンケ 一ト調査であり、食料品の購入先とともに利用頻 度、購入額や買い物についての意識、食品の摂取 状況等についての回答が得られた $[21]($ 註 5$) 。$

なお、本調查は買い物と食事に関する調査であ るため、流通加工業者を除いた農林水産業の生産 者モニター及び消費者モニターを対象とし、各モ ニターの世帯で普段食事の準備や調理をする者を 回答者としている。居住地については、あらかじ め登録されているモニター情報から農林水産省統 計部内において該当メッシュコードを割り当て、 それらとアクセスマップを接続し、店舗までの平 均距離をあてはめた（註 6 )。

\section{3. 店舗の利用可能性からみた食料品購入の 実態}

1 ）回答者の属性

まず、回答者の記述統計を表 1 に示す。65歳未 満、65歳以上の年齢層別に示している。2つの年 齢階層に共通して、回答者のおよそ8 割が女性で 
表 1 回答者の属性

\begin{tabular}{|c|c|c|}
\hline$(\mathrm{n})$ & $\begin{array}{c}\text { 65歳未満 } \\
(1,314)\end{array}$ & $\begin{array}{c}\text { 65歳以上 } \\
(886)\end{array}$ \\
\hline \multicolumn{3}{|l|}{ 性別 } \\
\hline 男性 & 16.4 & 20.3 \\
\hline 女性 & 83.6 & 79.7 \\
\hline \multicolumn{3}{|l|}{ モニター（世帯主の職業） } \\
\hline 農業者 & 34.9 & 56.6 \\
\hline 林業者 & 3.0 & 7.5 \\
\hline 漁業者 & 11.6 & 11.6 \\
\hline 消費者 & 50.5 & 24.4 \\
\hline \multicolumn{3}{|l|}{ 世帯員数 } \\
\hline 1人 & 4.2 & 4.7 \\
\hline 2人 & 22.2 & 44.9 \\
\hline 3 人以上 & 73.6 & 50.3 \\
\hline \multicolumn{3}{|l|}{ 最利用店舗 } \\
\hline スーパー & 90.94 & 93.12 \\
\hline 地元小売店 & 3.81 & 4.18 \\
\hline コンビニ & 4.19 & 1.81 \\
\hline \multicolumn{3}{|l|}{ 最寄り店舗 ～～～～} \\
\hline スーパー & 41.27 & 49.66 \\
\hline 地元小売店 & 15.26 & 19.95 \\
\hline コンビニ & 39.51 & 25.62 \\
\hline \multicolumn{3}{|l|}{ 移動手段 } \\
\hline 徒歩 - 自転車 & 14.5 & 10.6 \\
\hline 車・バイク & 77.6 & 78.9 \\
\hline 家族等の車 & 7.6 & 10.1 \\
\hline 公共交通等 & 0.3 & 0.5 \\
\hline
\end{tabular}

出所：筆者作成。

ある。また、世帯主の最利用店舗までの移動手段 として「車・バイク」と回答していることが挙げ られる。両年齢階層ともに公共交通機関の利用は ほとんどみられなかった。最寄り店舗と最利用店 舗との回答比率には大きな差が見られ、最利用店 舗がスーパーであるがそれが最寄り店舗ではない ことが推察される（註 7 ）。

年齢階層によって違いが見られたこととして、 65歳未満では半数が消費者モニター、65歳以上で は半数が農業者モニターであったことを指摘でき る。

\section{2 ）店舗までの距離と主観的指標}

次に、本研究では店舗までの距離を食料品アク セスの客観的指標として用いるが、買い物におけ る不便や苦労である主観的指標との関連も確認す る（表 $2 ）($ 註 8 ）。不便ありと不便なしの店舗ま での距離の差に着目すると、65歳未満が444m（= 2,762-2,317）に対して、65歳以上では1,309m（=
表2 店舖までの距離と主観的指標

\begin{tabular}{|c|c|c|c|c|}
\hline$(\mathrm{n})$ & $\begin{array}{c}\text { 65歳 } \\
\text { 不便なし } \\
(923)\end{array}$ & $\begin{array}{c}\text { 未満 } \\
\text { 不便あり } \\
(391)\end{array}$ & $\begin{array}{c}\text { 65歳 } \\
\text { 不便なし } \\
(689)\end{array}$ & $\begin{array}{l}\text { 以上 } \\
\text { 不便あり } \\
(197)\end{array}$ \\
\hline 全体 & 2,317 & 2,762 & 3,070 & 4,379 \\
\hline \multicolumn{5}{|l|}{ モニター } \\
\hline 農業者 & 3,026 & 3,572 & 3,182 & 4,619 \\
\hline 林業者 & 6,468 & 9,325 & 7,357 & 6,125 \\
\hline 漁業者 & 4,413 & 6,376 & 4,272 & 6,895 \\
\hline 消費者 & 1,016 & 1,261 & 1,058 & 1,992 \\
\hline \multicolumn{5}{|l|}{ 最利用店舗 } \\
\hline スーパー & 2,234 & 2,708 & 3,026 & 4,128 \\
\hline 地元小売店 & 4,490 & 4,830 & 4,348 & 7,078 \\
\hline コンビニ & 2,310 & 2,208 & 2,649 & 6,117 \\
\hline \multicolumn{5}{|l|}{ 最寄り店舗 } \\
\hline スーパー & 1,623 & 1,969 & 2,469 & 3,822 \\
\hline 地元小売店 & 4,359 & 4,832 & 4,950 & 6,234 \\
\hline コンビニ & 2,258 & 2,318 & 2,709 & 3,346 \\
\hline \multicolumn{5}{|l|}{ 移動手段 ～～～～} \\
\hline 徒歩 $\cdot$ 自転車 & 775 & 948 & 953 & 1,532 \\
\hline 車・バイク & 2,484 & 3,328 & 3,349 & 4,466 \\
\hline 家族等の車 & 3,164 & 2,488 & 3,167 & 6,511 \\
\hline 公共交通等 & 568 & 937 & 495 & 3,285 \\
\hline
\end{tabular}

出所：筆者作成。

4,379-3,070）であり、その差がより大きいこと が確認できる（註 9$)$ 。すなわち、65歳以上の高 齢者においては買い物における不便ありの理由と して距離の要因が強いことが推察される。従って、 65歳以上においては客観的指標として店舗までの 距離が主観的指標の代理変数となりうることが確 認された。そのため、店舗までの距離を本研究の 分析指標として用いる。モニター別では消費者に 比へ、農業者・林業者・漁業者（以下、生産者） では、店舗までの平均距離が大きいことが示され ている。

最利用店舗や最寄り店舗別では、コンビニの距 離が最も小さく、地元小売店の距離が最も大きい サブグループも見受けられる。ここからもコンビ 二の急拡大と地元小売店の衰退がうかがわれる。

3 ）店舗利用頻度と購入額

年齢階層別および店舗までの距離別に一人あた りの利用頻度と購入額を表 3 に示した（註10）。 小売業態別の利用頻度や購入額はいずれもスーパ 一が最も多い。食料品の購入において、スーパー がメインで利用され、地元小売店、コンビニは補 完的に利用されていることが分かる。次項におい 


\section{フードシステム研究第 27 巻 4 号 2021. 3}

表 3 小売業態別利用頻度と購入額

\begin{tabular}{|c|c|c|c|c|c|c|c|c|}
\hline \multirow{3}{*}{ （店舗まで） } & \multicolumn{4}{|c|}{ 65歳未満 } & \multicolumn{4}{|c|}{ 65歳以上 } \\
\hline & \multicolumn{2}{|c|}{ 500m未満 } & \multicolumn{2}{|c|}{$500 \mathrm{~m}$ 以上 } & \multicolumn{2}{|c|}{ 500m未満 } & \multicolumn{2}{|c|}{$500 \mathrm{~m}$ 以上 } \\
\hline & $\begin{array}{c}\text { 利用頻度 } \\
\text { (回/週) }\end{array}$ & $\begin{array}{l}\text { 購入額 } \\
(\text { 円週) }\end{array}$ & $\begin{array}{c}\text { 利用頻度 } \\
\text { (回/週) }\end{array}$ & $\begin{array}{l}\text { 購入額 } \\
\text { (円/週) }\end{array}$ & $\begin{array}{c}\text { 利用頻度 } \\
\text { (回/週) }\end{array}$ & $\begin{array}{l}\text { 購入額 } \\
\text { (円/週) }\end{array}$ & $\begin{array}{c}\text { 利用頻度 } \\
\text { (回/週) }\end{array}$ & $\begin{array}{l}\text { 購入額 } \\
\text { (円/週) }\end{array}$ \\
\hline スーパー & 3.41 & 5,665 & 2.94 & 5,740 & 3.55 & 7,271 & 2.93 & 6,822 \\
\hline 地元小売店 & 0.57 & 735 & 0.67 & 1,162 & 0.84 & 2,497 & 0.68 & 1,779 \\
\hline コンビニ & 1.50 & 775 & 1.43 & 1,043 & 0.90 & 1,662 & 0.83 & 1,020 \\
\hline
\end{tabular}

出所：筆者作成。

表 4 店舗の利用可能性・利用の組合せ（65歳以上）

\begin{tabular}{|c|c|c|c|c|c|c|c|c|c|}
\hline \multirow[b]{3}{*}{ 小売業態数 } & \multirow{3}{*}{$\begin{array}{l}\quad \text { (移動手段) } \\
\text { 組合せ }\end{array}$} & \multicolumn{4}{|c|}{ 利用可能性 } & \multicolumn{4}{|c|}{ 実際の利用 } \\
\hline & & \multicolumn{2}{|c|}{ 自動車以外 } & \multicolumn{2}{|c|}{ 自動車 } & \multicolumn{2}{|c|}{ 自動車以外 } & \multicolumn{2}{|c|}{ 自動車 } \\
\hline & & 人数 & $\%$ & 人数 & $\%$ & 人数 & $\%$ & 人数 & $\%$ \\
\hline 3 & $\begin{array}{c}\text { スーパー、地元小売店、 } \\
\text { コンビニ全て }\end{array}$ & 77 & 77.8 & 634 & 80.6 & 7 & 7.1 & 89 & 11.3 \\
\hline \multirow{3}{*}{2} & スーパー、地元小売店 & 3 & 3.0 & 10 & 1.3 & 22 & 22.4 & 94 & 11.9 \\
\hline & スーパー、コンビニ & 10 & 10.1 & 72 & 9.1 & 18 & 18.4 & 167 & 21.2 \\
\hline & 地元小売店、コンビニ & 0 & 0.0 & 2 & 0.3 & 1 & 1.0 & 3 & 0.4 \\
\hline \multirow{3}{*}{1} & スーパー & 7 & 7.1 & 67 & 8.5 & 48 & 49.0 & 423 & 53.7 \\
\hline & 地元小売店 & 1 & 1.0 & 2 & 0.3 & 1 & 1.0 & 7 & 0.9 \\
\hline & コンビニ & 0 & 0.0 & 0 & 0.0 & 1 & 1.0 & 0 & 0.0 \\
\hline \multirow[t]{2}{*}{0} & - & 0 & 0.0 & 1 & 0.1 & 0 & 0.0 & 5 & 0.6 \\
\hline & 計 & 98 & 100.0 & 788 & 100.0 & 98 & 100.0 & 788 & 100.0 \\
\hline
\end{tabular}

出所：筆者作成。

てその組合せを確認する。

年齢階層別に見ると、65歳以上で店舗までの距 離が $500 \mathrm{~m}$ 以上の場合、各店舗の利用頻度および 購入額が低い傾向がみられた。買い物頻度が低く てもまとめ買いでそれを補っているわけではなく、 店舗まで遠い高齢者は食料品の購入が十分できて いない可能性があることが示唆された。

\section{4 ）店舗の利用可能性と利用実態}

次に、店舗の利用可能性と実際の利用実態につ いて検討するが、最利用店舗までの移動手段が自 動車か否かでこれらの様相が異なることが予想さ れる。特に65歳以上において顕著となるであろう。 そこで、表 4 には65歳以上を対象に店舗の組合せ を利用可能性と実際の利用について、最利用店舗 までの移動手段が自動車（以下、自動車）と徒歩 や自転車、公共交通などの自動車以外 (以下、自 動車以外）に分けて示した。店舗の利用可能性と して、スーパー、地元小売店、コンビニの全ての 小売業態を利用可能な回答者は移動手段にかかわ らず、8 割程度存在したことから、多くの回答者 が全ての小売業態を利用可能である食環境にある
ことが推察できる。

実際に利用する店舗の組合せとしては、移動手 段にかかわらず最も多い組合せがスーパーのみで あり、特定の小売業態に特化していることが確認 された。次に多い店舗の組合せとして、自動車以 外ではスーパーと地元小売店、自動車ではスーパ ーとコンビニであった。これには店舗の品揃えが 影響しているとみられ、自動車以外では限られた 範囲で必要なものを揃えるためスーパーや地元小 売店での買い物が中心になるが、自動車が利用で きると品揃えが豊富なスーパーを買い回り、コン ビニを補完的に利用しているとも解釈できる（註 11)。このことは、表 1 で確認したように、最利 用店舗はスーパーであるがそれが最寄りの店舗で はないことからも示唆される。

\section{4. 店舗の利用可能性からみた食料品アクセ スと食品摄取}

ここでは店舗の利用可能性と食品檪取の関係を 定量的に検討するが、その際各店舗の利用可能夕゙ ミー変数がメインの説明変数となる。係数の解釈 
表 5 因子分析の結果

\begin{tabular}{lcccc}
\hline \multicolumn{1}{c}{ 変数名 } & こだわり志向 & 経済性志向 & Uniqueness & $\begin{array}{c}\text { クロンバック } \\
\text { の } \alpha\end{array}$ \\
\hline 健康に良い食品をよく食べる & $\underline{\mathbf{0 . 7 4 4}}$ & -0.097 & 0.479 & \\
栄養バランスには気を付けている & $\underline{\mathbf{0 . 7 5 3}}$ & -0.076 & 0.461 & \\
カロリー、塩分、脂質をひかえるようにしている & $\underline{\mathbf{0 . 6 5 1}}$ & 0.005 & 0.574 & 0.77 \\
外食先で地元産の食材をよく食べる & $\underline{\mathbf{0 . 4 8 2}}$ & 0.250 & 0.635 & \\
地元产を選んで購入することが多い & $\underline{\mathbf{0 . 5 2 4}}$ & 0.126 & 0.671 & \\
\hline 食品は少しでも安いところで買う & 0.007 & $\underline{\mathbf{0 . 6 9 7}}$ & 0.511 \\
值引きされた食品をよく買う & -0.031 & $\underline{\mathbf{0 . 7 4 9}}$ & 0.452 & \\
なるべく食を費をさえるようにしている & 0.061 & $\underline{\mathbf{0 . 6 8 1}}$ & 0.508 & 0.74 \\
忙しいので食事を準備する時間がない & -0.019 & $\underline{\mathbf{0 . 4 3 4}}$ & 0.816 & \\
\hline
\end{tabular}

出所 : 筆者作成。

は当該店舗が利用不可能な場合との差となる。例 えば、コンビニ利用可能ダミーの係数は、コンビ 二以外の店舗（スーパー、地元小売店）の利用可 能性を同じとした時（註12）のコンビニが利用可 能な人と利用不可能な人の差を意味する。

また、食品摂取の多様性は店舗の利用可能性だ けでなく、様々な要因によって影響を受ける。そ のため、薬師寺 $[1]$ を参考に需要要因と供給要 因に整理してコントロールすべき説明変数を検討 する。なお、(1)供給要因として、距離（注目する 変数：店舗までの距離)、需要要因として(2)回答 者の年齢・性別・食生活志向・世帯主の職業（注 目する変数：年齢・男性ダミー・食生活志向の因 子得点、生産者ダミー) (3)回答者の家族構成（注 目する変数：世帯員数) (4)回答者が属する世帯の 経済状況（注目する変数：月あたり食費）を取り 上げる（註13）。

分析に先立ち、普段の食生活に関する 9 項目に ついて 4 件法で尋ねた質問項目に対して全年齢を 対象に因子分析を行った。因子の抽出法は最尤法、 因子の回転法はKaiserの正規化を伴うプロマック ス法を用いた。分析の結果を表 5 に示す。なお、 因子負荷量が $0.400 に$ 満たない項目は、当該因子 の構成から除外している。

その結果、2つの因子が抽出された。1つは 「健康に良い食品をよく食べる」「栄養バランスに は気を付けている」「カロリー、塩分、脂質をひか えるようにしている」「外食先で地元産の食材をよ く食べる」「地元産を選んで購入することが多い」 から構成されている。これらは食へのこだわりが 強い傾向が確認できるため「こだわり志向」と名 付けた。もう 1 つの因子は「食品は少しでも安い
ところで買う」「值引きされた食品をよく買う」「な るべく食費を扮さえるようにしている」「忙しいの で食事を準備する時間がない」という項目から構 成され「経済性志向」と名付けた。これら因子の 因子得点を食生活の志向を表す説明変数として Tobitモデルに用いる。これまでに挙げた注目す る変数について、それぞれの定義と記述統計量を 表 6 に示す。

上述した変数を説明変数として、食品摂取の多 様性得点と摂取頻度を目的変数とするTobitモデ ルの推計を行った。その際、最利用店舗への移動 手段が自動車か否かでサブサンプルに分割して推 計を行った。なお、推計にはStata15を用いた。 推計結果を表 7 に示す（註14）。

店舗の利用可能ダミーについて、自動車におい て有意な值を示した。多様性得点および緑黄色野 菜、果物類の摂取頻度に対して、コンビニダミー の係数が有意な正值を示した。魚介類の摂取頻度 に対して、スーパーダミー、地元小売店ダミーの 係数が有意な正值を示した。(1)供給要因として、 客観的指標である店舗までの距離の係数は、最利 用店舗への移動手段が自動車以外の場合では、食 品摂取の多様性得点および緑黄色野菜、果物類の 摂取頻度に対して有意な負值を示した。一方、自 動車の場合は有意な值を示さなかった。すなわち、 店舗までの距離が大きく、移動手段が自動車以外 では、多様性得点および緑黄色野菜、果物類の摂 取頻度が低くなることが示唆される。

以下、需要要因であるが、(2)回答者の年齢・性 別・食生活の志向を示す変数に関して、移動手段 が自動車の場合においては、年齢の係数が魚介類 の摂取頻度に有意な正值を示した。 
フードシステム研究第 27 巻 4 号 2021. 3

表 6 分析に用いる変数の記述統計

\begin{tabular}{|c|c|c|c|c|}
\hline \multirow[t]{2}{*}{ (n) } & \multicolumn{2}{|c|}{$\begin{array}{c}\text { 自動車以外 } \\
(98)\end{array}$} & \multicolumn{2}{|c|}{$\begin{array}{l}\text { 自動車 } \\
(788)\end{array}$} \\
\hline & 平均 & 標準偏差 & 平均 & 標準偏差 \\
\hline \multicolumn{5}{|l|}{ 〈目的変数〉 } \\
\hline 多様性得点(点) & 4.17 & 2.47 & 4.04 & 2.51 \\
\hline \multicolumn{5}{|l|}{ 摂取頻度(回/週) } \\
\hline 緑黄色野菜 & 5.72 & 1.85 & 5.51 & 2.19 \\
\hline 果物類 & 4.82 & 2.50 & 3.83 & 2.53 \\
\hline 肉類 & 4.01 & 2.12 & 3.87 & 2.17 \\
\hline 魚介類 & 4.43 & 2.14 & 4.68 & 2.27 \\
\hline \multicolumn{5}{|l|}{ 〈説明変数〉 } \\
\hline \multicolumn{5}{|l|}{ 店舗の利用可能性 } \\
\hline スーパーダミー & 0.99 & 0.10 & 0.99 & 0.08 \\
\hline 地元小売店ダミー & 0.83 & 0.38 & 0.82 & 0.38 \\
\hline コンビニダミー & 0.89 & 0.32 & 0.90 & 0.30 \\
\hline 店舗までの距離 (km) & 1.14 & 2.22 & 3.64 & 4.02 \\
\hline \multicolumn{5}{|l|}{ 世帯属性 ～～～～～} \\
\hline 生産者ダミー & 0.32 & 0.47 & 0.81 & 0.39 \\
\hline 男性ダミー & 0.24 & 0.43 & 0.20 & 0.40 \\
\hline 年齢 & 72.73 & 5.15 & 71.19 & 4.96 \\
\hline 世帯員数 & 2.42 & 1.12 & 3.14 & 1.49 \\
\hline \multicolumn{5}{|l|}{ ひと月当たり食費 (円/人) } \\
\hline 食費 2-3 万円ダミー & 0.31 & 0.50 & 0.32 & 0.50 \\
\hline $\begin{array}{l}\text { 食費 } 3 \text { 万円以上ダミー } \\
\text { 食生活の志向 }\end{array}$ & 0.37 & 0.34 & 0.26 & 0.24 \\
\hline こだわり志向 & 0.17 & 0.82 & 0.03 & 0.80 \\
\hline 経済性志向 & -0.14 & 0.76 & -0.29 & 0.77 \\
\hline
\end{tabular}

出所 : 筆者作成。

食生活の志向においては、こだわり志向の因子 得点の係数がほとんどの推計において有意な正值 を示し、経済性志向の因子得点の係数は移動手段 が自動車の場合、食品摂取の多様性得点および緑 黄色野菜と果物類の摂取頻度に対して有意な負值 を示した。(3)回答者の家族構成について、世帯員 数は食品摂取の多様性得点、肉類では有意な正值、 果物類では有意な負值を示した。(4)回答者が属す る世帯の経済状況として、ひと月当たり食費は、 移動手段が自動車以外の場合では、有意な值を示 さなかったが、自動車の場合では全ての推計にお いて有意に正值を示した。需要要因の傾向をまと めると、食費が高い人、食へのこだわりが強い人 は多様性得点、および各食品群の摂取頻度が高い 傾向が示唆された。

\section{5. 結論}

本研究では店舗の利用可能性に着目し、消費者 の食料品購入の実態と特徴を明らかにし、さらに
小売業態の視点から食料品アクセスと食品摂取の 関係を定量的に検討した。

まず、回答者の利用する店舗別に概観した結果、 65歳以上では買い物における不便や苦労の有無別 で店舗までの距離の差が大きく、不便の理由とし て距離の要因が強いことが推察された。加えて65 歳以上では店舗からの距離が大きい場合、買い物 頻度が低い傾向にあること、および購入額も低い 傾向が見られた。これらのことから、店舗へのア クセスが困難な高齢者は買い物頻度が低く買い物 1 回あたり購入額も小さい、すなわちまとめ買い では食生活をカバーしきれず、食品摂取の多様性 とともに生鮮食品の摂取頻度に悪影響が出ている 可能性が示唆された。

次に、最利用店舗への移動手段が自動車か否か でサブサンプルに分割して、食品摂取の多様性得 点と摂取頻度を目的変数、店舗の利用可能性をメ インの説明変数とするTobitモデルを推計した。 その結果、65歳以上において、最利用店舗への移 動手段が自動車の場合、多様性得点および緑黄色 
店舗の利用可能性からみた食料品アクセスと食品摂取

表 7 Tobitモデルの推計結果

\begin{tabular}{|c|c|c|c|c|c|c|c|c|c|c|c|c|c|c|c|c|c|c|}
\hline \multirow{3}{*}{$\begin{array}{l}\text { (被説明変数) } \\
\text { (移動手段) }\end{array}$} & \multicolumn{6}{|c|}{ 多様性得点 } & \multicolumn{6}{|c|}{ 緑黄色野菜 } & \multicolumn{6}{|c|}{ 果物類 } \\
\hline & \multirow{2}{*}{\multicolumn{3}{|c|}{$\begin{array}{c}\text { 自動車以外 } \\
\text { 係数＼cjkstart標準誤差 }\end{array}$}} & \multirow{2}{*}{\multicolumn{3}{|c|}{$\begin{array}{c}\text { 自動車 } \\
\text { 係数 標準誤差 }\end{array}$}} & \multirow{2}{*}{\multicolumn{3}{|c|}{$\begin{array}{c}\text { 自動車以外 } \\
\text { 係数＼cjkstart標準誤差 }\end{array}$}} & \multirow{2}{*}{\multicolumn{3}{|c|}{$\begin{array}{c}\text { 自動車 } \\
\text { 係数 標準誤差 }\end{array}$}} & \multirow{2}{*}{\multicolumn{3}{|c|}{$\begin{array}{c}\text { 自動車以外 } \\
\text { 係数 標準䛊差 }\end{array}$}} & \multirow{2}{*}{\multicolumn{3}{|c|}{$\begin{array}{cl} & \text { 自動車 } \\
\text { 係数 標準誤差 }\end{array}$}} \\
\hline & & & & & & & & & & & & & & & & & & \\
\hline \multicolumn{19}{|l|}{ 店舗の利用可能性 } \\
\hline スーパーダミー & 1.18 & $(2.45)$ & & 0.74 & (1.18) & & 1.81 & $(3.95)$ & & -2.45 & $(2.61)$ & & 2.39 & $(4.49)$ & & -0.08 & $(1.75)$ & \\
\hline 地元小売店ダミー & -0.28 & $(0.72)$ & & -0.02 & $(0.30)$ & & 0.45 & $(1.35)$ & & -0.06 & $(0.75)$ & & 0.41 & $(1.44)$ & & -0.39 & $(0.47)$ & \\
\hline コンビニダミー & -0.05 & (1.08) & & 0.70 & $(0.41)$ & $\dagger$ & 1.07 & (1.96) & & 3.03 & $(0.96)$ & $* *$ & -3.46 & $(2.21)$ & & 1.34 & $(0.63)$ & $*$ \\
\hline 店舗までの距離 & -0.28 & $(0.13)$ & $*$ & -0.01 & $(0.02)$ & & -0.37 & $(0.22)$ & $\dagger$ & -0.01 & $(0.06)$ & & -0.50 & $(0.24)$ & $*$ & 0.02 & $(0.04)$ & \\
\hline \multicolumn{19}{|l|}{ 世帯属性 } \\
\hline 生産者ダミー & -0.18 & $(0.64)$ & & -0.62 & $(0.25)$ & $* *$ & -1.07 & $(1.25)$ & & -2.21 & $(0.69)$ & $* *$ & -3.55 & $(1.28)$ & $* *$ & -2.57 & $(0.42)$ & $* *$ \\
\hline 男性ダミー & -1.66 & $(0.57)$ & $* *$ & -0.60 & $(0.23)$ & $* *$ & -3.15 & $(1.06)$ & ${ }^{* *}$ & -1.79 & $(0.54)$ & ** & -1.63 & $(1.13)$ & & -0.32 & $(0.35)$ & \\
\hline 年齢 & -0.06 & $(0.05)$ & & 0.02 & $(0.02)$ & & -0.03 & $(0.09)$ & & -0.02 & $(0.05)$ & & -0.01 & $(0.10)$ & & -0.03 & $(0.03)$ & \\
\hline 世帯員数 & -0.31 & $(0.23)$ & & 0.13 & $(0.06)$ & * & -0.29 & $(0.45)$ & & 0.13 & $(0.15)$ & & -0.05 & $(0.46)$ & & -0.22 & $(0.10)$ & $*$ \\
\hline \multicolumn{19}{|c|}{ ひと月当たり食費(円/人) } \\
\hline 2 万円未満(基準) & - & & & - & & & - & & & - & & & - & & & - & & \\
\hline $2-3$ 万円ダミー & 0.55 & $(0.63)$ & & 0.39 & $(0.22)$ & $\dagger$ & -0.71 & $(1.24)$ & & -0.33 & $(0.52)$ & & 0.93 & $(1.29)$ & & 1.00 & $(0.34)$ & $* *$ \\
\hline 3 万円以上ダミー & 0.36 & $(0.64)$ & & 0.56 & $(0.23)$ & ** & -0.05 & $(1.27)$ & & 0.74 & $(0.57)$ & & 0.88 & $(1.33)$ & & 0.62 & $(0.36)$ & $\dagger$ \\
\hline \multicolumn{19}{|l|}{ 食生活の志向 } \\
\hline こだわり志向 & 1.01 & $(0.32)$ & $*$ & 0.90 & $(0.13)$ & ** & 1.51 & $(0.58)$ & $*$ & 2.23 & $(0.30)$ & $* *$ & 1.75 & $(0.63)$ & * & 1.10 & $(0.20)$ & $* *$ \\
\hline 経済性志向 & 0.43 & $(0.36)$ & & -0.23 & $(0.13)$ & $*$ & -1.12 & $(0.73)$ & & -0.65 & $(0.31)$ & $*$ & 0.05 & $(0.72)$ & & -0.01 & $(0.20)$ & $* *$ \\
\hline 定数項 & 1.60 & (4.48) & & 0.28 & (1.83) & & 9.71 & (8.17) & & 8.17 & (4.31) & & 9.33 & $(8.92)$ & & 7.97 & $(2.80)$ & \\
\hline 都道府県ダミー & \multicolumn{3}{|c|}{ No } & \multicolumn{3}{|c|}{ Yes } & \multicolumn{3}{|c|}{ No } & \multicolumn{3}{|c|}{ Yes } & \multicolumn{3}{|c|}{ No } & \multicolumn{3}{|c|}{ Yes } \\
\hline サンプルサイズ & \multicolumn{3}{|c|}{98} & \multicolumn{3}{|c|}{788} & \multicolumn{3}{|c|}{98} & \multicolumn{3}{|c|}{788} & \multicolumn{3}{|c|}{98} & \multicolumn{2}{|c|}{788} & \\
\hline 疑似決定係数 & \multicolumn{3}{|c|}{0.08} & & 0.05 & & & 0.12 & & & 0.08 & & & 0.11 & & & 0.06 & \\
\hline 最大VIF & & 2.22 & & & 3.15 & & & 2.22 & & & 3.15 & & & 2.22 & & & 3.15 & \\
\hline
\end{tabular}

\begin{tabular}{|c|c|c|c|c|c|c|c|c|c|c|}
\hline \multirow{3}{*}{$\begin{array}{l}\text { (被説明変数) } \\
\text { (移動手段) }\end{array}$} & \multicolumn{5}{|c|}{ 肉類 } & \multicolumn{5}{|c|}{ 魚介類 } \\
\hline & \multicolumn{2}{|c|}{ 自動車以外 } & \multicolumn{3}{|c|}{ 自動車 } & \multicolumn{2}{|c|}{ 自動車以外 } & \multicolumn{3}{|c|}{ 自動車 } \\
\hline & 係数 & 標準誤差 & 係数 & 標準誤差 & & 係数 & 標準誤差 & 係数 & 標準誤差 & \\
\hline \multicolumn{11}{|l|}{ 店舗の利用可能性 } \\
\hline スーパーダミー & 3.05 & $(2.92)$ & 0.84 & $(1.29)$ & & -16.49 & $(535.29)$ & 3.28 & $(1.70)$ & $\dagger$ \\
\hline 地元小売店ダミー & 0.51 & $(0.87)$ & -0.42 & $(0.34)$ & & 0.28 & $(0.97)$ & 0.90 & $(0.46)$ & * \\
\hline コンビニダミー & 1.12 & $(1.30)$ & 0.40 & $(0.47)$ & & -0.39 & (1.51) & -0.40 & $(0.64)$ & \\
\hline 店舗までの距離 & 0.23 & $(0.16)$ & 0.00 & $(0.03)$ & & -0.18 & $(0.17) \dagger$ & 0.04 & $(0.04)$ & \\
\hline \multicolumn{11}{|l|}{ 世帯属性 } \\
\hline 生産者ダミー & 0.35 & $(0.78)$ & -0.20 & $(0.29)$ & & 1.23 & $(0.89)$ & 1.12 & $(0.40)$ & ** \\
\hline 男性ダミー & -1.59 & $(0.69)^{*}$ & -0.68 & $(0.26)$ & $*$ & -0.25 & $(0.76)$ & -0.35 & $(0.36)$ & \\
\hline 年齢 & 0.09 & $(0.06)$ & 0.01 & $(0.02)$ & & 0.09 & $(0.06)$ & 0.07 & $(0.03) *$ & * \\
\hline 世帯員数 & 0.27 & $(0.29)$ & 0.30 & $(0.07)$ & ** & -0.38 & $(0.32)$ & -0.05 & $(0.10)$ & \\
\hline \multicolumn{11}{|l|}{$\begin{array}{l}\text { ひと月当たり食費 (円／ } \\
\text { 人) }\end{array}$} \\
\hline 2 万円未満(基準) & - & & - & & & - & & - & & \\
\hline 2 - 3 万円ダミー & -0.58 & $(0.78)$ & 0.53 & $(0.25)$ & $\dagger$ & -0.01 & $(0.87)$ & 0.56 & $(0.34)$ & $\dagger$ \\
\hline 3 万円以上ダミー & -0.08 & $(0.78)$ & 0.27 & $(0.27)$ & $*$ & 1.20 & $(0.87)$ & 1.25 & $(0.37)$ & ** \\
\hline 食生活の志向 & & & & & & & & & & \\
\hline こだわり志向 & 0.38 & $(0.38)$ & 0.76 & $(0.14)$ & ** & 0.81 & $(0.43) \dagger$ & 0.48 & $(0.20)$ & * \\
\hline 経済性志向 & 0.31 & $(0.44)$ & -0.18 & $(0.15)$ & & 0.35 & $(0.50)$ & -0.26 & $(0.20)$ & \\
\hline 定数項 & -7.08 & (5.45) & 1.28 & $(2.07)$ & & 15.22 & $(535.31)$ & -4.20 & (2.83) & \\
\hline 都道府県ダミー & \multicolumn{2}{|c|}{ No } & \multicolumn{3}{|c|}{ Yes } & \multicolumn{2}{|c|}{ No } & \multicolumn{3}{|c|}{ Yes } \\
\hline サンプルサイズ & \multicolumn{2}{|r|}{98} & \multicolumn{3}{|c|}{788} & \multicolumn{2}{|r|}{98} & \multicolumn{3}{|c|}{788} \\
\hline 疑似決定係数 & \multicolumn{2}{|r|}{0.04} & \multicolumn{3}{|c|}{0.04} & \multicolumn{2}{|c|}{0.04} & \multicolumn{3}{|c|}{0.05} \\
\hline 最大VIF & \multicolumn{2}{|r|}{2.22} & \multicolumn{3}{|c|}{3.15} & \multicolumn{2}{|c|}{2.22} & \multicolumn{2}{|c|}{3.15} & \\
\hline
\end{tabular}

出所：筆者作成。

註：**、*、†は、それぞれ $1 \% 、 5 \% 、 10 \%$ 水準で統計的に有意であることを示している。

野菜と果物類の摂取頻度を目的変数とした推計で コンビニダミー変数が有意な正值を示した。すな わち、最利用店舗へは自動車を利用しなければい けないほど遠いが、袋入りカット野菜など簡便な
緑黄色野菜や果物類をコンビニで補完的に購入す ることで食品摂取の多様性を維持していることが 推察される。コンビニまで自動車を利用できる高 齢者では、野菜や果物の摂取が高まるなど食生活 
に影響を及ぼしている可能性が示唆された（註 15)。伊藤ら［16］でも指摘されているが、コン ビニの利用は一般的に「不健康」と結び付けられ やすいが、近年では健康にも配慮した中食商品の 導入や生鮮食品の取り扱い拡大によって、高齢者 の食生活改善に貢献する可能性があると言えよう。 また、移動手段が自動車以外の回答者は店舗ま での距離が大きいほど、食品摂取の多様性にそし く、緑黄色野菜と魚介類の摂取頻度が低い傾向が 確認された。他方、移動手段が自動車の場合、店 舗までの距離と食品摂取との関連は認められなか った。これは店舗まで $500 \mathrm{~m}$ 以上で自動車の利用 が困難な65歳以上といったアクセスマップの定義 と整合的である。

店舗の利用可能ダミー変数の係数が意味すると ころは、店舗が存在することの食生活に及ぼす総 合的な影響であるため、各店舗を拠点とした移動 販売車や宅配サービス等への取組が今回の分析に も少なからず影響している。最近はコンビニも 「ラストワンマイル」をめぐる争いに加わってお

り、移動販売や宅配に取り組む事例が見受けられ る。今後の動向に注目したい。

(註 1 ) 商業統計にみる小売業商店数の推移や小売業 態別の動向の詳細に関しては小本［2]、高橋 ［3］を参照されたい。

(註 2 ) 各食品について最近一週間の摂取頻度を尋ね、 「ほとんど毎日」摂取していると回答した場合に 1 点加点される。食品の摂取頻度はこの設問にお ける「ほとんど毎日」を 7 日、「 2 日に 1 回」を 3.5日、「1 週間に $1 \sim 2$ 回」を 1.5 日、「ほとんど 食べない」を 0 日と日数換算した。

（註３）アクセスマップに拈いて、アクセス困難者と は店舗まで $500 \mathrm{~m}$ 以上かつ自動車を利用できない 65歳以上の高齢者としている。

（註 4) ここでの移動手段とは、食料品の買い物で最 もよく利用する打店までどのような交通手段を用 いるかを尋ね、選択肢として「徒歩又は自転車」 「あなたが運転する自動車、バイク」「家族・知り 合いが運転する車」「バス、タクシー、鉄道（買い 物バス、乗り合いバスを含む。」を設けている。 このうち、「あなたが運転する自動車、バイク」 「家族・知り合いが運転する車」選択した回答者 である。
（註 5 ）本調査の調査対象は農林水産情報交流ネット ワーク事業の全国47都道府県の農林水産業の生産 者、消費者からなるモニターである。各都道府県 にモニターのタイプごとに人数が割り当てられ、 各農政局が公募しているため、地域に偏りなくサ ンプルが抽出されている。任期は 2 年である。本 研究のために特別にモニターを公募したわけでは ない。

調査対象は買い物及び食事の準備を行う人に限 定しており、農林漁業者モニターの消費者として の側面を捉えている。モニターのタイプは、世帯 主の職業として位置づけられ、それを考慮した分 析を実施している。

（註 6 ）平均距離の算出方法は薬師寺 [22］と同様の 方法であり、詳細についてはこちらを参照された い。概要としては以下の通りである。

最寄り店舗までの距離が $500 \mathrm{~m}$ 以上である確率 を算出する際の計算過程を利用して、100m未満 から $70 \mathrm{~km}$ 以上まで区間ごとに確率を算出し、区 間の中心値と該当区間の確率から平均距離（距離 の期待值）が得られる。

最寄り店舗までの距離が $500 \mathrm{~m}$ 以上である確率 の算出方法に関して、あるメッシュ $j$ 内の任意の 位置 $k$ において店舗までの距離が $500 \mathrm{~m}$ 以上であ る確率を計算する。位置 $k$ を中心に $500 \mathrm{~m}$ の円を 描いた時、円の外側に店舗が存在する確率は、当 該および周辺のメッシュに打ける円とメッシュが 重ならない面積の割合と店舗数の積である。メッ シュ $j$ 内の他の位置でも同様に確率を求め平均を とる。

（註 7 ）この最利用店舗と最寄り店舗の違いは、アク セスマップの定義では店舗まで $500 \mathrm{~m}$ 未満であれ ばアクセス困難者とはみなされないが、実際には 店舗まで $500 \mathrm{~m}$ 未満であってもアクセス困難者が 存在する可能性を示唆している。

（註 8 ）主観的指標として「あなたは普段、食料品の 買い物で不便や苦労がありますか」に対して「不 便や苦労がある」「不便や苦労が時々ある」「不便や 苦労はあまりない」「不便や苦労は全くない」の 4 つの選択肢を設けた。「不便や苦労がある」「不便 や苦労時々ある」と回答した者を「不便あり」と し「不便や苦労はあまりない」「不便や苦労は全く ない」と回答した者を「不便なし」としている。

（註 9 ）表中の数値は四捨五入しているため、差は一 致しない。

（註10）利用頻度に「ほとんど毎日」を 7 日、「2 日に 
1 回」を3.5日、「1 週間 に $1 \sim 2$ 回」を 2 日、 「ほとんど利用しない」を 0 日と日数換算して平 均值を算出し、購入額は利用頻度に買い物一回あ たりの購入額を乗じて算出した。なお、買い物一 回当たりの購入額は世帯員の平方根で除して、等 価支出額としている。

（註11）店舗の利用可能性と実際の利用の厳密な比較 には、利用可能な店舗が同じ回答者を対象にする ことが求められる。全ての小売業態が利用可能な 回答者（自動車以外：77名、自動車634名）の実 際の利用を確認しても、同様の傾向であった。紙 幅の都合上、表の掲載は割愛する。

（註12）具体的には(1)スーパーのみ利用可能(2)地元小 売店のみ利用可能(3)スーパーと地元小売店の両方 が利用可能のいずれかの状況を指す。

（註13）「近くに別居している家族」(薬師寺 [1]）や、 車で約1.5時間程度と必ずしも空間的には近いと は言えない他出子（徳野 [23]）の役割は大きい。 今回は十分に考慮できていないため、こうした実 態を反映するデー夕収集と分析を今後の課題とし たい。

（註14）スーパーダミー・地元小売店ダミー・コンビ ニダミーの属性相関係数はいずれも 0.8 未満であ り、本研究の問題意識に照らして、過小定式化の 弊害を回避するためにこのモデルをあえて採用し ている。なお、1 1)コンビニダミーのみのモデルや (2)地元小売店ダミー・コンビニダミーを残したモ デルの推計では表 7 の結果と差異はない。

（註15）消費者モニターは農林水産行政に関心があり、 多様性得点や各摂取頻度が高い方向に偏っている 点を考慮すれば、サンプルセレクションの可能性 も考えられる。ただ「こだわり志向」や「経済性 志向」など意識を抽出し処置は行っている。

\section{参考文献}

[1]薬師寺哲郎編著『超高齢社会における食料品ア クセス問題－買い物難民、買い物弱者、フードデ ザート問題の解決に向けてー』ハーベスト社、 2015。

［2］小本恵照『小売業店舗戦略の経済分析』NTT出 版、2000。

[3]高橋克也「食品流通 $2 」$ 薬師寺哲郎、中川隆編 著『フードシステム入門 : 基礎からの食料経済学』 建帛社、第 6 章、2019、pp.51-60。

[4]高橋克也「食料品アクセス問題の現状と今後『平成 27 年国勢調查』に基づく新たな食料品アク
セスマップの推計からー」『フードシステム研究』 25 ( 3 )、2018、pp.119-128。

［5］宮腰美希・大塚美佳・加藤めぐみ 他「若年労働 者のコンビニエンスストアを利用した食事摂取内 容と労働状況に関する実態調査」『産業衛生学雑』 50 (3) 、2008、pp.92-99。

[6] Solar, O. and Irwin, A. (2010), "A conceptual framework for action on the social determinants of health", Social Determinants of Health Discussion Paper 2 (Policy and Practice), WHO, 2010.

[7] Story, M., Kaphingst, K M., Robinson-O'Brien, R., and Glanz, K. "Creating Healthy Food and Eating Environments: Policy and Environmental Approaches”, Annual Review of Public Health, 29, 2008, pp.253-272.

[8] USDA, Access to Affordable and Nutritious Food: Measuring and Understanding Food Deserts and Their Consequences Report to Congress, USDA, 2009.

[9] Morland, K., Diez, Roux, A V., and Wing, S. "Supermarkets, Other Food Stores, and Obesity: The Atherosclerosis Risk in Communities Study", American Journal of Preventive Medicine, 30 (4), 2006, pp.333-339.

[10] Cobb, L K., Appel, L J., Franco, M., Jones-Smith, J C., Nur, A., and Anderson, C A. M. "The Relationship of the Local Food Environment with Obesity: A Systematic Review of Methods, Study Quality, and Results", Obesity, 23(7), pp.1331-1344.

[11] Dubowitz T, Ghosh-Dastidar M, Cohen DA. et al. "Diet and Perceptions Change with Supermarket Introduction in A Food Desert, But Not Because of Supermarket Use", Health Affairs, 2015, 34(11), pp.1858-68.

[12] Cummins S, Flint E, Matthews SA. "New Neighborhood Grocery Store Increased Awareness of Food Access But Did Not Alter Dietary Habits or Obesity" Health Affairs, 2014, 33(2), pp.283-91.

[13］岩間信之・今井具子 - 田中耕市 他「食料品充足 率を加味した食料品アクセスマップの開発」『フー ドシステム研究』25（3)、2018、pp.81-96。

[14] 浅川達人 - 岩間信之 ・田中耕市 他「食料品充 足率を加味したアクセス測定指標による食品摂取 
多様性の分析：高龄者の健康的な食生活維持に対 する阻害要因のマルチレベル分析」『フードシステ 么研究』26（2)、2019、pp. 21-34。

[15] 大橋めぐみ・高橋克也・菊島良介 他「高齢女 性の食料品アクセスが食生活と健康におよぼす影 響の分析：地方都市中心市街地に打ける食品スー パー開店後の住民調査より」『フードシステム研 究』2017、24、pp.61-71。

［16］伊藤暢宏・菊島良介・高橋克也「食料品購買于 ヤネル選択と食料品摂取の関係 - 選択の同時決定 性を考慮したアプローチー」『フードシステム研 究』25（4)、2019、pp.245-250。

[17］菊島良介・高橋克也「食料品アクセス問題にお ける買い物サービス利用が食品摂取の多様性に及 ぼす影響：農林水産情報交流ネットワーク事業全 国調查結果の分析」『農林水産政策研究』29、2018、 pp. $29-42$ 。

[18] Yamaguchi M., Takahashi K., Hanazato M., Suzuki N., Kondo K., Kondo N. "Comparison of Objective and Perceived Access to Food Stores Associated with Intake Frequencies of Vegetables/Fruits and Meat/Fish among Community-Dwelling Older Japanese”, International Journal of Environmental Research and Public Health, 16(5), 2019, 772.

[19］菊島良介・高橋克也「国民健康・栄養調查から みた食料品アクセスと栄養打よび食品摂取：代 替・補完関係に着目して」『日本公衆衛生雑誌』67 (4)、2020、pp. 261-271。

[20］熊谷修 - 渡辺修一郎 - 柴田博 他「地域在宅高齢 者に扔ける食品摂取の多様性と高次生活機能低下 の関連」『日本公衆衛生雑誌』50（12）、2003、 pp.1117-1124。

[21］農林水産省「平成30年度農林水産情報交流ネッ トワーク事業全国調査：買い物と食事に関する意 識・意向調查 (平成30年 7 月調查) 」https:// www.maff.go.jp/j/finding/mind/attach/pdf/ index-12.pdf（2020年 2 月閲覧）。

[22］薬師寺哲郎・高橋克也「食料品アクセス問題に おける店舗への近接性－店舗までの距離の計測に よる都市と農村の比較－」『フードシステム研究』 20 ( 1)、2013、pp.14-25。

[23］徳野貞雄監修・牧野厚史・松本貴文編『暮らし の視点からの地方再生 : 地域と生活の社会学』九 州大学出版会、2015。

[2020年 4 月 8 日受付、2021年 1 月31日受理］ 